Bioeduca: Journal of Biology Education
$\frac{\text { http://iournal.walisongo.ac.id/index.php/bioeduca }}{\text { ISSN 2714-8009 (print), 2715-7490 (online) }}$
Volume 3, Nomor 2, Tahun 2021
Hal. 91-98

\title{
Analisis Kemandirian Belajar Biologi Siswa MAN Pada Masa Pandemi
}

\author{
Ulfatun Muyasaroh ${ }^{1}$, Listyono ${ }^{2}$, Ndzani Latifatur Rofi' ah ${ }^{3}$ \\ ${ }_{1,2,3}$ Prodi Pendidikan Biologi, Universitas Islam Negeri Walisongo Semarang \\ Email: ulfatunmuyasaroh07@gmail.com
}

\begin{tabular}{|c|c|}
\hline Informasi Artikel & ABSTRAK \\
\hline $\begin{array}{l}\text { Submit: } 10-07-2021 \\
\text { Diterima: } 15-09-2021 \\
\text { Dipublikasikan: } 30-09-2021\end{array}$ & $\begin{array}{l}\text { Covid-19 berpengaruh terhadap aspek pendidikan, pembelajaran } \\
\text { yang semula tatap muka berubah menjadi pembelajaran daring. } \\
\text { Guru menjelaskan materi pembelajaran secara online, sehingga } \\
\text { siswa harus lebih mandiri dalam memahami materi dan } \\
\text { menyelesaikan tugas. Penelitian in bertujuan menganalisis } \\
\text { kemandirian belajar siswa pada pembelajaran daring. Jenis } \\
\text { penelitiaan ini kuantitatif deskriptif dengan metode survei. } \\
\text { Instrumen pengumpulan data berbentuk angket skala likert yang } \\
\text { disebar melalui google form. Teknik pengambilan sampel yang } \\
\text { digunakan adalah probability sampling dengan jenis simple } \\
\text { random sampling. Teknik analisis data menggunakan statistik } \\
\text { deskriptif. Hasil penelitian menunjukkan kemandirian belajar } \\
\text { terdapat enam indikator, yaitu tujuan belajar (74,48 \%), strategi } \\
\text { belajar ( } 75,62 \%) \text {, manajemen waktu ( } 79,34 \%) \text {, lingkungan } \\
(84,43 \%), \text { pencarian bantuan ( } 77,34 \%) \text {, dan evaluasi diri ( } 74,85 \\
\%) \text { Tingkat kemandirian belajar siswa pada pembelajaran daring } \\
\text { dikategorikan tinggi. } \\
\text { Kata kunci: kemandirian belajar; pembelajaran biologi; } \\
\text { pembelajaran daring. }\end{array}$ \\
\hline Penerbit & $\begin{array}{ll}\text { ABSTRACT } \\
\end{array}$ \\
\hline $\begin{array}{l}\text { Program Studi Pendidikan } \\
\text { Biologi, Fakultas Sains dan } \\
\text { Teknologi, UIN Walisongo } \\
\text { Semarang }\end{array}$ & $\begin{array}{l}\text { Covid-19 affects aspects of education, learning that was } \\
\text { originally face-to-face has turned into online learning. Teachers } \\
\text { explain learning materials online, so students must be more } \\
\text { independent in understanding the material and completing } \\
\text { assignments. This study aims to teach students in bold learning } \\
\text { independently. This type of quantitative descriptive research with } \\
\text { survey method. The data collection instrument is in the form of a } \\
\text { Likert scale questionnaire distributed via a google form. The } \\
\text { sampling technique used is probability sampling with the type of } \\
\text { simple random sampling. The data analysis technique used } \\
\text { descriptive statistics. The results of the study of learning } \\
\text { independence contained six indicators, namely learning } \\
\text { objectives (74.48\%), learning strategies (75.62 \%), time } \\
\text { management (79.34\%), environment (84.43\%), seeking help } \\
\text { (77. } 34 \%) \text {, and self-evaluation (74.85\%). The level of student } \\
\text { learning independence in online learning was categorized as } \\
\text { high. } \\
\text { Keywords: independent learning; biology learning; online } \\
\text { learning }\end{array}$ \\
\hline
\end{tabular}

Copyright $\odot 2021$, Bioeduca: Journal of Biology Education 


\section{PENDAHULUAN}

Wabah virus corona atau Covid-19 (Corona Virus Disease-19), muncul pertama kali di Wuhan, Hubei, China dan menyebar ke seluruh negara di dunia (Rahmasari dkk, 2020). Kasus penyebaran Covid-19 semakin cepat dan meluas, hingga jumlah peningkatan kasusnya tidak bisa diduga. Pandemi Covid-19 sudah berjalan satu tahun di Indonesia, namun kasus positif semakin bertambah. Berdasarkan data Komite Penanganan Covid-19 dan Pemulihan Ekonomi Nasional (KPCPEN) pada 18 Maret 2021 penambahan kasus positif Covid-19 mencapai 1.443 .853 orang (KPCPEN, 2021).

Pandemi Covid-19 mengakibatkan perubahan di negara Indonesia dalam aspek kehidupan mulai dari aspek ekonomi, sosial, budaya, agama dan pendidikan (Kusuma dkk, 2020). Surat Edaran Nomor 4 Tahun 2020 tentang Pelaksanaan Kebijakan Pendidikan Dalam Masa Darurat Penyebaran Coronavirus Disease (COVID-19) yang dikeluarkan oleh Menteri Pendidikan dan Kebudayaan Republik Indonesia, menjelaskan bahwa pembelajaran dilaksanakan secara daring (Mendikbud RI, 2020).

Perubahan dalam proses pembelajaran daring berpengaruh terhadap kemandirian belajar siswa (Muhammad, 2020). Menurut Marfu'ah (2020) siswa dalam pembelajaran daring adalah mereka yang membutuhkan materi dan model pembelajarannya online, misalnya diskusi secara online dengan guru dan teman, bahan ajar yang dikirimkan guru melalui platform pembelajaran daring, konsultasi, penugasan, serta ujian dilaksanakan secara daring. Siswa dalam proses pembelajaran daring dituntut lebih mandiri dalam menyelesaikan tugas dan memahami materi pelajaran yang tidak bisa dijelaskan keseluruhan oleh guru. Jika terdapat materi yang belum dipahami, siswa harus aktif dalam mencari sumber referensi secara mandiri karena terbatasnya ruang interaksi sesama teman dan guru (Muhammad, 2020). Siswa yang mengikuti pembelajaran daring perlu menjadi siswa yang memiliki motivasi diri, mandiri, dan bertanggung jawab (Gilbert, 2015).

Menurut Friantini dan Winata (2020) kemandirian belajar merupakan kemampuan siswa untuk dapat mengontrol aspek kognisi, memonitor, meregulasi serta memotivasi perilaku siswa itu sendiri ketika belajar. Kemandirian belajar memiliki rasa tanggung jawab di dalam diri seseorang dalam menerapkan dan merancang serta mengevaluasi belajarnya. Kemandirian belajar sangat penting bagi siswa dalam proses pelaksanaan pembelajaran daring, khususnya pada materi pelajaran biologi. Mata pelajaran biologi adalah bagian dari bidang sains yang menuntut untuk belajar pada tingkat tinggi secara menyeluruh. Siswa dikatakan berhasil jika membuktikan pemahamannya pada jenjang kemampuan yang lebih tinggi, baik konteks sama maupun beda (Ritongga, 2020).

Arista dan Kuswanto (2018) mengungkapkan bahwa kemandirian belajar siswa merupakan aspek yang sangat penting dalam mendukung efektivitas kegiatan pembelajaran. Hal ini diperkuat oleh Gilbert (2015) bahwa kemandirian belajar juga 
diyakini sebagai salah satu komponen penting suksesnya pembelajaran jarak jauh. Menurut Bunandar (2016) kemandirian belajar siswa dapat dilihat dari pemanfaatan

sumber belajar dan kemampuan manajemen waktu, artinya dalam proses pencapaian pemahaman siswa tidak bergantung pada materi yang diberikan oleh guru.

Berdasarkan wawancara salah satu guru biologi di MAN 1 Grobogan dan MAN 2 Grobogan, beliau mengatakan bahwa proses pembelajaran daring menggunakan e-learning dari sekolah dan Whatshapp Group untuk memantau siswa yang belum absen, mengirim materi jika e-learning terdapat kendala dan siswa yang terlambat dalam pengumpulan tugas. Metode yang digunakan oleh guru yaitu mengirim materi berbentuk ppt, word, dan pdf yang nantinya akan dipelajari oleh siswa di rumah. Hal tersebut yang membuat siswa harus lebih mandiri dalam memahami materi dan menyelesaikan tugas yang diberikan oleh guru. Berdasarkan uraian tersebut, penelitian dengan judul "Analisis Kemandirian Belajar Biologi Siswa MAN Pada Masa Pandemi" perlu dilakukan.

\section{METODE PENELITIAN}

Jenis penelitian ini adalah kuantitatif deskriptif dengan metode survei. Penelitian deskriptif dilakukan untuk mengetahui nilai masing-masing variabel, baik satu variabel atau lebih (independent) tanpa membuat perbandingan atau penghubungan dengan variabel yang lain (Khoiri, 2018:6). Menurut Sugiyono (2016) penelitian kuantitatif adalah penelitian yang berlandaskan pada filsafat positivisme, digunakan untuk meneliti pada populasi atau sampel tertentu. Data kuantitatif diperoleh dari analisis skor pada jawaban subjek terhadap angket mengenai kemandirian belajar siswa. Penelitian ini dilakukan di MAN 1 Grobogan dan MAN 2 Grobogan pada bulan April di semester genap tahun 2020/2021. Populasi dalam penelitian ini adalah seluruh siswa kelas X dan XI di MAN 1 dan MAN 2 Grobogan. Teknik pengambilan sampel yang digunakan adalah probability sampling dengan jenis simple random sampling. Teknik pengumpulan data berupa angket kemandirian belajar yang dibagikan kepada siswa melalui google form. Skala yang digunakan adalah skala likert 1-5.

Indikator serta daftar pernyataan kuesioner mengenai kemandirian belajar siswa diadaptasi dari penelitian yang dilakukan oleh Makur et al (2021).

Tabel 1. Kisi-Kisi Instrumen Kemandirian Belajar

\begin{tabular}{llcc}
\hline \multicolumn{1}{c}{ Variabel } & \multicolumn{2}{c}{ Indikator } & \multicolumn{2}{c}{ Nomor Item } \\
\cline { 2 - 4 } & & Positif & Negatif \\
\hline Kemandirian & Tujuan belajar & $1,2,3,4$ & 5,6 \\
\cline { 2 - 4 } belajar & Strategi belajar & 7,8 & 9,10 \\
\cline { 2 - 4 } & Manajemen waktu & 11,12 & 14 \\
\cline { 2 - 4 } & Lingkungan & 13,15 & 19 \\
\cline { 2 - 4 } & Pencarian bantuan & 16,17 & 10 \\
\cline { 2 - 4 } & Evaluasi diri & 18 & \\
\hline
\end{tabular}


Analisis data menggunakan statistik deskriptif, data yang digunakan berdasarkan skor jawaban siswa dari angket kemandirian belajar siswa yang diberikan. Data dari angket dalam penelitian ini merupakan data kuantitatif yang akan dianalisis dalam bentuk persentase.

Nilai persentase hasil penskoran siswa $(X)$ dengan menggunakan rumus :

$$
\begin{aligned}
& X=\frac{\sum x i}{S} \times 100 \% \\
& \text { Keterangan : } \\
& \begin{array}{l}
\sum x i \quad=\text { jumlah skor yang diperoleh } \\
S \quad=\text { total skor seluruhnya }
\end{array}
\end{aligned}
$$

Tabel 2. Interpretasi Skor

\begin{tabular}{ccc}
\hline No. & Interval Persentase Skor & Kriteria \\
\hline 1. & $85 \leq \%$ skor $\leq 100$ & Sangat Tinggi \\
\hline 2. & $69 \leq \%$ skor $\leq 84$ & Tinggi \\
\hline 3. & $53 \leq \%$ skor $\leq 68$ & Sedang \\
\hline 4. & $37 \leq \%$ skor $\leq 52$ & Rendah \\
\hline 5. & $20 \leq \%$ skor $\leq 36$ & Sangat Rendah \\
\hline
\end{tabular}

(Sumber: Setyosari, 2016:234)

\section{HASIL PENELITIAN DAN PEMBAHASAN}

Penelitian ini dilakukan selama 1 minggu, mulai tanggal 19-24 April 2021. Subjek penelitian ini adalah siswa kelas $X$ dan XI MIPA, setiap jenjang di ambil dua kelas. MAN 1 Grobogan terdapat 6 kelas yaitu X MIPA 1-6 dan XI MIPA 1-6. Dua kelas yang diambil secara acak adalah kelas X MIPA 1 dan 2, dan XI MIPA 1 dan 2. MAN 2 Grobogan terdapat 3 kelas yaitu X MIPA 1-3 dan XI MIPA 1-3. Dua kelas yang diambil secara acak adalah kelas X MIPA 1 dan 2, dan XI MIPA 2 dan 3. Jumlah seluruh responden pada penelitian ini sebanyak 241 siswa.

Tabel 3. Data Distribusi Persentase Tingkat Kemandirian Belajar Siswa

\begin{tabular}{cccc}
\hline Interval & Kriteria & Frekuensi & Persentase \\
Persentase Skor & Sangat Tinggi & 62 & $25,73 \%$ \\
\hline $85 \leq \%$ skor $\leq 100$ & Tinggi & 137 & $56,85 \%$ \\
\hline $69 \leq \%$ skor $\leq 84$ & Sedang & 42 & $17,43 \%$ \\
\hline $53 \leq \%$ skor $\leq 68$ & Rendah & 0 & $0 \%$ \\
\hline $37 \leq \%$ skor $\leq 52$ & Sangat Rendah & 0 & $0 \%$ \\
\hline $20 \leq \%$ skor $\leq 36$ & & 241 & $100 \%$ \\
\hline Jumlah & & & 0 \\
\hline
\end{tabular}

Hasil penelitian menunjukkan bahwa dari 241 siswa terdapat 62 siswa $(25,73$ $\%)$ memiliki tingkat kemandirian belajar sangat tinggi, 137 siswa (56,85\%) memiliki tingkat kemandirian belajar tinggi dan 42 siswa $(17,43 \%)$ memiliki tingkat kemandirian belajar sedang, sehingga tingkat kemandirian belajar siswa dominan tinggi. Hal ini dapat dilihat dari beberapa indikator seperti tujuan belajar, strategi belajar, manajemen waktu, lingkungan, pencarian bantuan, serta evaluasi diri. Indikator mengenai kemandirian belajar siswa di MAN se Grobogan dapat dilihat melalui perhitungan analisis persentase indikator sebagai berikut. 
Tabel 4. Data Rata-Rata Persentase Jawaban Indikator

\begin{tabular}{clcc}
\hline No. & Indikator & Persentase tiap Indikator & Kategori \\
\hline 1. & Tujuan belajar & $74,48 \%$ & Tinggi \\
\hline 2. & Strategi belajar & $75,62 \%$ & Tinggi \\
\hline 3. & Manajemen waktu & $79,34 \%$ & Tinggi \\
\hline 4. & Lingkungan & $84,43 \%$ & Sangat Tinggi \\
\hline 5. & Pencarian bantuan & $77,34 \%$ & Tinggi \\
\hline 6. & Evaluasi diri & $74,85 \%$ & Tinggi \\
\hline \multicolumn{2}{l}{ Rata-rata keseluruhan } & $77,68 \%$ & Tinggi \\
\hline
\end{tabular}

Indikator tujuan belajar diperoleh hasil sebesar $74,48 \%$, hal ini menunjukkan bahwa indikator tujuan belajar berada pada kategori tinggi. Siswa yang terlibat dalam mata pelajaran biologi telah menetapkan tujuan dan target yang akan dicapai meskipun proses pembelajaran dilaksanakan secara daring. Selain itu, siswa mempunyai standar tinggi untuk tugas-tugas maupun kuis yang diberikan oleh guru sehingga siswa menyediakan waktu untuk mempelajari mata pelajaran biologi. Berdasarkan penelitian (Ambiyar et al 2020) tujuan belajar yang telah ditetapkan siswa sangat penting, dapat dilihat dari sikap siswa dalam menentukan tujuan belajar untuk mendukung proses belajar, serta menyusun jadwal belajar untuk mencapai tujuan yang telah ditetapkan.

Indikator strategi belajar, berdasarkan hasil penelitian diperoleh sebesar 75,62 $\%$, hal ini menunjukkan bahwa siswa memiliki strategi belajar berada pada kategori tinggi. Siswa memprioritaskan tugas mata pelajaran biologi dan bertekad dapat menyelesaikan tugas tersebut. Siswa mempersiapkan diri sebelum pembelajaran daring dimulai dengan membaca materi terlebih dahulu. Menurut Sihotang et al 2020) strategi belajar mandiri yang efektif selama pembelajaran daring yakni berlatih mengelola waktu yang baik, membaca cepat, serta merekam hasil baca, misalnya dengan membuat resume, outline, dan peta konsep.

Indikator manajemen waktu, berdasarkan hasil penelitian indikator manajemen waktu diperoleh hasil sebesar 79,34\%, hal ini menunjukkan bahwa siswa memiliki manajemen waktu berada pada kategori tinggi. Ketika siswa belajar online, mereka akan membagi waktu khusus untuk belajar dan menyelesaikan tugas biologi yang diberikan oleh guru, sehingga siswa bisa menemukan waktu yang tepat dalam belajar. Berdasarkan penelitian Susanty (2020) proses pembelajaran daring harus bisa menetapkan manajemen waktu, karena manajemen waktu sangat menentukan keberhasilan dalam mengerjakan tugas. Siswa yang belum terbiasa belajar mandiri, umumnya mengerjakan tugas pada menit-menit terakhir dengan batas waktu yang sudah ditetapkan.

Indikator lingkungan, berdasarkan hasil penelitian indikator lingkungan diperoleh hasil sebesar $84,43 \%$, hal ini menunjukkan bahwa indikator lingkungan berada pada kategori tinggi. Siswa mencari kondisi lingkungan yang cocok untuk mendukung proses pembelajaran daring, seperti mencari tempat yang nyaman, sinyal internet yang mendukung, dan suasana yang tidak terlalu ramai. Kondisi tersebut dapat membantu siswa secara efektif agar tidak terganggu dalam proses belajar. Menurut Jaelani et al (2020) proses pembelajaran daring bagi siswa sangat 
membutuhkan sinyal internet yang mendukung, karena sinyal sebagai media penyalur pembelajaran yang tidak sepenuhnya bisa terakses dengan baik karena perbedaan wilayah yang ditempati oleh siswa.

Indikator pencarian bantuan, berdasarkan hasil penelitian diperoleh sebesar $77,34 \%$, hal ini menunjukkan bahwa indikator pencarian bantuan berada pada kategori tinggi. Siswa menggunakan saluran komunikasi interaktif berupa WhatsApp untuk berpartisipasi dalam forum diskusi dan mendapat dukungan dari teman kelas mengenai materi pelajaran biologi. WhatsApp Group digunakan sebagai forum diskusi siswa untuk memperoleh informasi mengenai materi yang belum dipahami serta tugas yang dibagikan oleh guru, sehingga siswa aktif dalam pembelajaran. Partisipasi siswa dalam forum diskusi menjadikan salah satu penilaian afektif dengan memberikan nilai berupa poin kepada siswa Kurniati et al (2021).

Indikator yang terakhir yaitu evaluasi diri, berdasarkan hasil penelitian diperoleh sebesar 74,85 \%, hal ini menunjukkan bahwa indikator evaluasi diri berada pada kategori tinggi. Siswa melakukan refleksi dan evaluasi hasil belajar yang telah dicapai dengan berpartisipasi dalam proses pembelajaran daring. Evaluasi diri bagi siswa ditinjau dari hasil proses belajar. Siswa senang dengan nilai yang diperolehnya, jika ada nilai yang kurang baik maka siswa harus semangat memperbaiki nilainya (Marfu'ah, 2020).

Berdasarkan uraian hasil analisis persentase setiap indikator kemandirian belajar siswa dengan jumlah 19 pernyataan, rata-rata persentase keseluruhan indikator kemandirian belajar sebesar $77,68 \%$. Hal ini menunjukkan bahwa indikator kemandirian belajar berada pada kategori tinggi, sehingga hal ini mengakibatkan tingkat kemandirian belajar siswa selama pembelajaran daring dikategorikan tinggi. Kemandirian belajar terdapat enam indikator, dari keenam indikator hasil rata-rata paling tinggi adalah indikator lingkungan dengan hasil persentase 84,43\% dan indikator yang menghasilkan persentase paling rendah adalah indikator tujuan belajar sebesar 74,48 \%. Hal ini sejalan dengan penelitian Koroh (2020) lingkungan belajar di masa pandemi menghasilkan rata-rata tinggi, dijelaskan bahwa pembelajaran daring lebih disukai daripada pembelajaran tatap muka. Siswa dapat mengakses informasi dari mana saja, dan dapat meningkatkan kemampuan literasi. Menurut Hidayat et al (2020) pembelajaran jarak jauh atau daring memungkinkan siswa untuk mengakses informasi pengetahuan dari rumah serta di manapun siswa berada sesuai dengan kenyamanan siswa.

Indikator tujuan belajar menghasilkan persentase rata-rata rendah dibanding dengan indikator yang lainnya karena dalam proses pembelajaran daring beberapa siswa tidak memiliki tujuan belajar atau menerima berapapun nilai yang diperoleh (Marfu'ah, 2020). Pembelajaran daring dapat meningkatkan kemandirian belajar siswa dilihat dari penentuan tujuan belajar, strategi belajar, manajemen waktu, lingkungan, pencarian bantuan, dan evaluasi diri. Sejalan dengan penelitian Firman dan Rahman (2020) pembelajaran daring di masa pandemi covid-19 dalam pelaksanaannya bersifat fleksibel sehingga mampu mendorong kemandirian belajar siswa untuk lebih aktif dalam belajar. 


\section{SIMPULAN DAN SARAN}

Berdasarkan hasil analisis data mengenai tingkat kemandirian belajar pada pembelajaran biologi siswa MAN di Kabupaten Grobogan pada masa pandemi, menunjukkan bahwa tingkat kemandirian belajar siswa berada pada kategori tinggi dengan enam indikator, yaitu tujuan belajar (74,48 \%), strategi belajar $(75,62 \%)$, manajemen waktu $(79,34 \%)$, lingkungan $(84,43 \%)$, pencarian bantuan $(77,34 \%)$, dan evaluasi diri $(74,85 \%)$.

Saran untuk siswa dalam penelitian ini yaitu siswa harus memiliki semangat belajar dan inisiatif belajar yang tinggi, mengingat pembelajaran tidak terpantau langsung oleh guru. Sedangkan saran untuk guru yaitu guru dapat meningkatkan dan mengembangkan kegiatan kemandirian belajar dengan cara memberikan tugas sesuai batas waktu yang sudah ditentukan dan memberikan feedback terhadap tugas yang dikerjakan oleh siswa.

\section{UCAPAN TERIMA KASIH}

Terimakasih kepada Kepala MAN 1 dan 2 Grobogan beserta staff yang telah memberikan izin untuk melaksanakan penelitian, guru biologi MAN 1 Grobogan dan MAN 2 Grobogan yang sudah banyak membantu terlaksananya penelitian ini.

\section{RUJUKAN}

Ambiyar, Aziz, I. dan Melisa. (2020). Perbedaan Kemandirian Belajar Siswa Pada Masa Pandemi di SMAN 1 Lembah Melintang Dan SMAN 1 Lembah Gumanti. Jurnal Cendekia, 04(02), 1246-1258.

Arista, F. S. dan Kuswanto, H. (2018). Virtual Physics Laboratory Application Based on the Android Smartphone to Improve Learning Independence and Conceptual

Understanding. International Journal of Instruction, 11(1), 1-16.

Bunandar, A. E. S. (2016). Analisis Kemandirian Belajar Siswa Pada Mata Pelajaran Biologi Di Kelas X Mas Al-Mustaqim Kubu Raya. Skripsi. Pontianakan: Universitas Muhammadiyah Pontianak.

Firman dan Rahman, S. R. (2020). Pembelajaran Online di Tengah Pandemi Covid19', Jurnal IImu Pendidikan Indonesia. 02(02), 81-89.

Friantini, R. dan Winata, R. (2020). Disposisi Matematis Dan Kemandirian Belajar Mahasiswa Pada Perkuliahan Daring Berbantuan Google Classroom Masa Covid-19. Jurnal Derivat, 7(2), 53-64.

Gilbert, B. (2015). Online Learning Revealing the Benefits and Challenges. Education Master. Paper 303.

Hidayat, D. R., Rohaya, A., Nadine, F., Ramadhan, H., \& Rawamangun. (2020). Kemandirian Belajar Peserta Didik Dalam Pembelajaran Daring Pada Masa Pandemi Covid -19. Jurnal Perspektif IImu Pendidikan, 34(2), 147-154.

Jaelany, Ahmad., Fauzi, Ahmad., Aisah, Heni., Zaqiyah, Qiqi Yuliyanti. (2020). Penggunaan Media Online dalam Proses Kegiatan Belajar Mengajar PAI Dimada Pandemi Covid-19. Jurnal Ikatan Alumni PGSD Unars, 8(1), 12-24.

Khoiri, Nur. (2018). Metodologi Penelitian Pendidiakan (Ragam, Model, \& Pendidikan). Semarang: Southeast Asian Publishing. 
Koroh, T. D. (2020). Respons Mahasiswa Terhadap Pembelajaran Daring Dan Kemandirian Belajar Mahasiswa Selama Pandemi Covid-19. Jurnal Balai Diklat Keagamaan Denpasar, 3, 54-59.

KPCPEN. (2021). Update Data Kasus Covid19. Diakses tanggal 18 Maret 2021 https://covid19.go.id

Kurniati, T, Irwan, R. Y., Asni, S. H., Devi, K., Dewi., \& I. (2021). Respon Guru Terhadap Kendala Proses Pembelajaran Biologi di Masa. Jurnal Education FKIP UNMA, 7(1), 40-46.

Kusuma, R. F., Sari, Y. and Khoirotun, N. (2020). Menumbuhkan Kemandirian Siswa Selama Pembelajaran Daring Sebagai Dampak Covid-19 di SD. Jurnal Riset Pendidikan Dasar, 7-13.

Makur, A.P., Emilianus, J., Sebastianus, F., Silfanus, J., Viviana, M., \& Polikarpus, R. (2021). Kemandirian Belajar Mahasiswa dalam Pembelajaran Jarak Jauh Selama Masa Pandemi. Jurnal Pendidikan Matematika, 10(1).

Marfu'ah, S. (2020). Analisis Kemandirian Belajar Siswa dalam Pembelajaran Matematika Secara Online Di SMP Negeri 1 Cilongok. Skripsi. Purwokerto: IAIN Purwokerto.

Mendikbud RI. (2020). Surat Edaran Nomor 4 Tahun 2020 Tentang Pelaksanaan Kebijakan Pendidikan Dalam Masa Darurat Penyebaran Coronavirus Disease (COVID-19).

Muhammad, I. (2020). Pengaruh Perkuliahan Daring Terhadap Kemandirian. Jurnal Ilmiah Pendidikan Matematika Al-Qalasadi, 4(1), 24-30.

Rahmasari, A. F., Setiawan, F. dan Nanda, M. (2020). Pengaruh Pembelajaran Online Terhadap Kemandirian Belajar Siswa Kelas II SD Muhammadiyah 17 Surabaya di Tengah Pandemi Covid-19. Jurnal Pendidikan Guru Sekolah Dasar, 04(2), 158-168.

Ritongga, I. D. (2020). Analisis Pembelajaran Daring dalam Menumbuhkan Ketrampilan Proses Sains Siswa pada Mata Pelajaran Biologo di SMA Negeri 1 Simangumban. Skripsi. Medan: UIN Sumatera Utara.

Setyosari, P. (2016). Metode Penelitian Pendidikan \& Pengembangan. Jakarta: Prenada Media.

Sihotang, H., Bernadetha, N. dan Rospita, S. (2020). Penerapan Belajar Mandiri Dengan Strategi Efektif Pada Masa Pandemi Covid 19 Bagi Remaja HKBP Duren Jaya Bekasi. Jurnal Comunita Servizio, 2(1), 393-405.

Sugiyono. (2016). Metode Penelitian Pendidikan (Pendekatan Kuantitatif, dan R\&D). Bandung: Alfabeta.

Susanty, S. (2020). Inovasi Pembelajaran Daring Dalam Merdeka Belajar. Jurnal Mataram, 9(2). 